\title{
Development of a database for the analysis of the disposal system in the representative preliminary safety analysis
}

\author{
Eva-Maria Hoyer, Paulina Müller, Phillip Kreye, Christoph Behrens, Marc Wengler, \\ Tobias Wengorsch, and Wolfram Rühaak \\ BGE mbH - Bundesgesellschaft für Endlagerung, \\ Federal Company for Radioactive Waste Disposal, 31224 Peine, Germany
}

Correspondence: Eva-Maria Hoyer (eva-maria.hoyer@bge.de)

Published: 10 November 2021

\begin{abstract}
The Federal Company for Radioactive Waste Disposal (BGE) is the German waste management organisation responsible for implementing the search for a site with the best possible safety for the disposal of high-level radioactive waste for at least 1 million years, following the amendments of the Repository Site Selection Act in 2017. The selection procedure is meant to be a participatory, transparent, learning and selfquestioning process based on scientific expertise. It consists of three phases with an increasing level of detail. The first step of the first phase of the site selection procedure was completed in September 2020 and resulted in the identification of 90 subareas that give reason to expect favourable geological conditions for the safe disposal. The potentially suitable subareas cover approximately $54 \%$ of Germany and are located in three different host rocks: rock salt (halite), claystone and crystalline rock.

The second step of phase one is currently in progress and includes the so-called representative preliminary safety analyses that aim to assess the extent to which the safe containment of the radioactive waste can be expected. Representative preliminary safety analyses are one of the foundations for deciding whether an area will be considered for surface-based exploration in the next phase of the site selection procedure. Within the preliminary safety analyses, the behaviour of the disposal system is analysed in its entirety, across all operational phases of the repository and under consideration of possible future evolution of the disposal system with respect to the safe containment of the radioactive waste.

The development of a database is described, which aims to systematically document and provide the framework needed for the analyses of the disposal systems in the subareas regarding the safe containment of the radionuclides over the assessment period of 1 million years. This database includes the vast amount of information about the different components of the disposal system. This includes also the geological setting, the technical conception of the repository and compilations of values for the physical, geoscientific, and technical parameters characterising the various barriers of the disposal system. Furthermore, a self-contained derivation of expected and deviating future evolution of the disposal system and its geological setting is included; following the so-called features, events and processes (FEP) strategy.
\end{abstract}

Kurzfassung. In Deutschland ist die Bundesgesellschaft für Endlagerung mbH (BGE) Vorhabenträgerin bei der Suche nach einem Standort, der für mindestens eine Million Jahre die bestmögliche Sicherheit für die Endlagerung hochradioaktiver Abfälle bieten soll, entsprechend der Änderung des Standortauswahlgesetzes im Jahr 2017. Das Standortauswahlverfahren ist als partizipativer, transparenter, auf wissenschaftlicher Expertise beruhender, lernender und sich selbst hinterfragender Prozess angelegt. Es besteht aus insgesamt drei Phasen mit zunehmendem Detaillierungsgrad, um den Standort mit der bestmöglichen Sicherheit zu ermitteln. Die erste Phase setzt sich aus zwei Schritten zusammen; Ziel des ersten Schritts war die Bestimmung von Teilgebieten in den drei betrachteten Wirtsgesteinen, Steinsalz, Tongestein und kristallines Wirtsgestein, unter Anwendung 
gesetzlich festgelegter Ausschlusskriterien, Mindestanforderungen und geowissenschaftlicher Abwägungskriterien. Insgesamt 90 Teilgebiete, die etwa $54 \%$ der Fläche Deutschlands ausmachen, wurden aufgrund ihrer günstigen geologischen Voraussetzungen ermittelt. Die Ergebnisse wurden im September 2020 veröffentlicht. Der zweite Schritt von Phase 1 wird derzeit bearbeitet und beinhaltet die repräsentativen vorläufigen Sicherheitsuntersuchungen, mit denen beurteilt werden soll, inwieweit ein sicherer Einschluss der radioaktiven Abfälle im untersuchten Teilgebiet zu erwarten ist.

Repräsentative vorläufige Sicherheitsuntersuchungen sind eine der Grundlagen für die Entscheidung, ob ein Gebiet in der nächsten Phase des Standortwahlverfahrens für eine übertägige Erkundung in Betracht gezogen wird. Im Rahmen der vorläufigen Sicherheitsuntersuchungen wird das Verhalten des Endlagers in seiner Gesamtheit über alle seine Phasen und unter Berücksichtigung möglicher zukünftiger Entwicklungen hinsichtlich des sicheren Einschlusses der radioaktiven Abfälle analysiert. Als Grundlage für die Analyse des sicheren Einschlusses von Radionukliden im Endlagersystem über den Bewertungszeitraum von einer Million Jahren, wird eine Datenbank entwickelt, die auch eine systematische Dokumentation gewährleisten soll. Diese Datenbank enthält Informationen über die verschiedenen Komponenten des Endlagersystems, wie z.B. die geologische Situation, die technische Auslegung des Endlagers und die Zusammenstellung von Werten zu physikalischen, geowissenschaftlichen und technischen Parametern, die die verschiedenen Barrieren des Endlagersystems charakterisieren. Darüber hinaus ist eine Ableitung von zu erwartenden und abweichenden zukünftigen Entwicklungen des Endlagersystems und seiner geologischen Gegebenheiten unter Anwendung einer FEP-Strategie (FEP: ,features, events and processes“) enthalten.

Acknowledgements. Too many colleagues have and will contribute in the process of nuclear waste site selection to be named here as abstract authors. However, their contributions are most important and valued. 